5. Blackett JW, Benvenuto L, Leiva-Juarez MM, D'Ovidio F, Arcasoy S, Jodorkovsky D. Risk factors and outcomes for gastroparesis after lung transplantation. Dig Dis Sci. September 15, 2021 [Epub ahead of print]. https://doi.org/10. 1007/s10620-021-07249-y

6. Hooft N, Smith M, Huang J, Bremner R, Walia R. Gastroparesis is common after lung transplantation and may be ameliorated by botulinum toxin-A injection of the pylorus. J Heart Lung Transplant. 2014;33:1314-6. https://doi.org/10.1016/j. healun.2014.08.016

7. Vitton V, Benoît D'Journo X, Reynaud-Gaubert M, Barthet M, Gonzalez JM Gastric peroral endoscopic myotomy (GPOEM) for severe gastroparesis after lung transplantation: a promising minimally invasive option. Clin Transplant. 2021;35:e14434. https://doi.org/10.1111/ctr.14434
See Article page 711.

\section{Commentary: Open your mind to an open pylorus}

\author{
Ross M. Bremner, MD, PhD
}

Delayed gastric emptying has long been a problem after lung transplantation. For various reasons, it appears to affect up to half of our patients. Although not always symptomatic, it invariably influences the transit and absorption of not only food but also essential medications. In poorly nourished patients, who also have concomitant nausea, delayed gastric emptying can be a devastating condition, impeding recovery from a big operation and often requiring some sort of enteral feeding-which brings its own set of challenges.

Historically, delayed gastric emptying has been troublesome to treat, and we have struggled to understand all the causes. Is it from gastroparesis (ie, loss of gastric motility) or a functional outflow obstruction from a denervated pylorus? Should we treat all causes similarly? Generally speaking, prokinetic drugs and pyloric outflow procedures have been the tools in our armamentarium. Erythromycin and metoclopramide have their place but need to be used with care, and usually for only short periods of time. Pyloric botulinum injection and dilation have also been used, ${ }^{1}$ but

\footnotetext{
From the Pulmonary and Lung Transplantation Division, Norton Thoracic Institute, St Joseph's Hospital and Medical Center, Phoenix, Ariz.

Disclosures: The author reported no conflicts of interest.

The Journal policy requires editors and reviewers to disclose conflicts of interest and to decline handling or reviewing manuscripts for which they may have a conflict of interest. The editors and reviewers of this article have no conflicts of interest.

Received for publication Nov 19, 2021; revisions received Nov 19, 2021; accepted for publication Nov 22, 2021; available ahead of print Nov 29, 2021.

Address for reprints: Ross M. Bremner, MD, PhD, Pulmonary and Lung Transplantation Division Norton Thoracic Institute, St Joseph's Hospital and Medical Center, 500 W Thomas Rd, Suite 500, Phoenix, AZ 85013 (E-mail: Ross.Bremner@ dignityhealth.org).

J Thorac Cardiovasc Surg 2022;164:721-2

$0022-5223 / \$ 36.00$

Copyright (c) 2021 by The American Association for Thoracic Surgery

https://doi.org/10.1016/j.jtcvs.2021.11.049
}

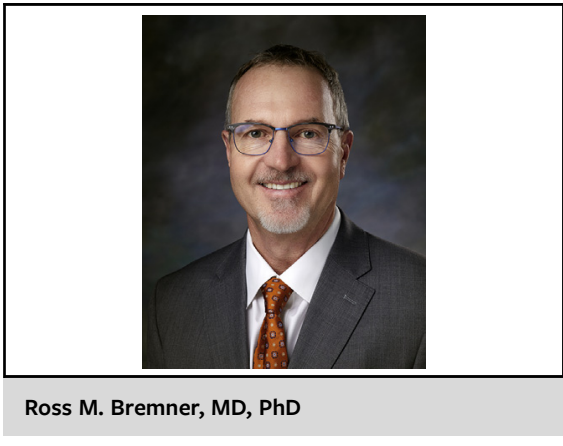

CENTRAL MESSAGE

Endoscopic pyloromyotomy is

presented as a judicious solution

to the complex problem of de-

layed gastric emptying in lung

transplant recipients and may

well become the procedure of

choice.

again these are usually temporary solutions, and when they wear off, medication absorption and serum levels of immunosuppressants may change, posing dosing challenges once again.

For recalcitrant patients, surgical pyloromyotomy or pyloroplasty has proven effective but carries the risk of potential surgical complications. However, endoscopic pyloromyotomy may minimize these complications while effectively correcting the outflow obstruction. As surgeons, our initial response to an endoscopic procedure mimicking our tried-and-tested surgical procedure is one of suspicion. The surgical fraternity has not completely accepted the option of endoscopic myotomy of the LES for achalasia as no antireflux procedure is added, but the pylorus does not need this added procedure. And although we have been worried about small perforations in the duodenum with potential devastating peritonitis in an immunocompromised patient, the authors have shown that this procedure, in the right 
hands and with the right experience, is indeed safe. ${ }^{2} \mathrm{I}$ do question their approach to adding endoscopic pyloromyotomy when a patient needs an antireflux procedure, as their argument that endoscopic pyloromyotomy may be superior to an open/laparoscopic procedure has yet to be proven. Nonetheless, we all should open our minds to the skills of the interventional gastroenterologist in performing these procedures, or learn to do them skillfully ourselves. The endoscopic pyloromyotomy may well become the best option for transplant recipients with troubling delayed gastric emptying. Thank you to the authors for recognizing this complex problem and providing such a great example of how this problem can be approached.

\section{References}

1. Hooft N, Smith M, Huang J, Bremner R, Walia R. Gastroparesis is common after lung transplantation and may be ameliorated by botulinum toxin-A injection of the pylorus. J Heart Lung Transplant. 2014;33:1314-6.

2. Rappaport J, Raja S, Gabbard S, Thuita L, Sanaka MR, Blackston EH, et al. Endoscopic pyloromyotomy is feasible and effective in improving post-lung transplant gastroparesis. J Thorac Cardiovasc Surg. 2022;164: 711-9.e4.
See Article page 711

\section{Commentary: Natural orifice management of postlung transplant gastroparesis}

\author{
Suha Kaaki, MD, and Matthew G. Hartwig, MD, MHS
}

The outcomes of lung transplant (LTx) have been improving over the years; however, the survival of our patients still lags behind other solid-organ recipients due to the high rate of complications. ${ }^{1}$ Previous studies found an association between delayed gastric emptying (DGE) and chronic lung allograft dysfunction (CLAD) ${ }^{2}$ and acute cellular rejection. ${ }^{3}$ Multiple mechanisms can contribute to this phenomenon, including (1) microaspiration, causing direct injury or vagal stimulation; (2) reflux of gastric content, causing vagally mediated bronchoconstriction; or (3) neuroinflammatory reflexes playing a role in the release of tachykinins, which cause airway responses. ${ }^{4}$ Hence, managing pre- or posttransplant DGE could potentially accomplish more than just alleviating the symptoms of DGE by also reducing the risk of CLAD.

From the Department of Cardiothoracic Surgery, Duke University Medical Center, Durham, NC.

Disclosures: The authors reported no conflicts of interest.

The Journal policy requires editors and reviewers to disclose conflicts of interest and to decline handling or reviewing manuscripts for which they may have a conflict of interest. The editors and reviewers of this article have no conflicts of interest.

Received for publication Nov 17, 2021; revisions received Nov 17, 2021; accepted for publication Nov 19, 2021; available ahead of print Nov 29, 2021.

Address for reprints: Suha Kaaki, MD, Department of Cardiothoracic Surgery, Duke University Medical Center, 2530 Erwin Rd, Durham, NC 27705 (E-mail: dr. kaaki@gmail.com).

J Thorac Cardiovasc Surg 2022;164:722-3

$0022-5223 / \$ 36.00$

Copyright (c) 2021 by The American Association for Thoracic Surgery

https://doi.org/10.1016/j.jtcvs.2021.11.047
Check for updates

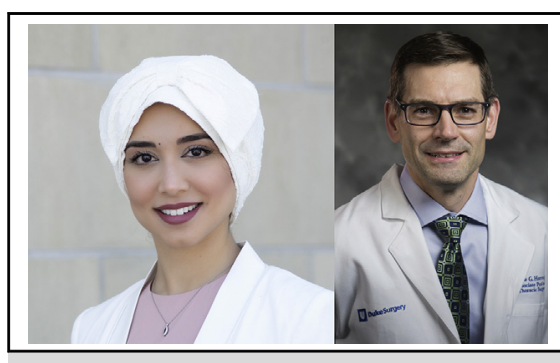

Suha Kaaki, MD, and Matthew G. Hartwig, MD, MHS

CENTRAL MESSAGE

Managing post-lung transplant

gastroparesis with the most-

effective, least-invasive way.

In this issue of the Journal, Rappaport and colleagues ${ }^{5}$ reported their experience with per-oral endoscopic pyloromyotomy (POP) in managing gastroparesis after LTx. The authors measured the main outcomes subjectively by Gastroparesis Cardinal Symptom Index and objectively by gastric emptying tests. Notably, their secondary objectives, which were the incidence of gastroesophageal reflux (GERD) and allograft function (forced expiratory volume in 1 second), are harder to directly correlate with gastric emptying but are of greater significance to the LTx recipient. Their results demonstrated significant improvement in Gastroparesis Cardinal Symptom Index and gastric emptying tests. GERD improved or remained stable in most 